\title{
Floor deliberations and beyond
}

The motion to lay on the table the motion to reconsider the vote by which the motion to lay on the table the motion to proceed to the consideration of the fair housing bill was rejected was agreed to. (Proceedings of the Senate, Congressional Record, 4 December 1980)

To the general public, the most visible parts of Congress are the debates which take place on the floor of the chambers of the House of Representatives and the Senate. Debates are televised live and can contain moments of great controversy and excitement. The most extreme incident took place during a debate in the chamber of the House of Representatives on 1 March 1954. As a quorum count was taking place of the 243 members present at that time, two men and a woman sitting in the public gallery jumped to their feet, and shouting 'Free Puerto Rico', pulled out Luger automatics and opened fire on the members below. Five Representatives were hit; all survived but the injuries left Alabama's Kenneth Roberts in a wheelchair for the next two years.

Most debates, however, are much more sedate. Indeed, visitors to Congress are often surprised by how few members are present during a typical debate. For low profile issues, or those which are technically complex, debates often take place with 
only a handful of members present. This situation can change suddenly; when a vote is called or a quorum count is to be held, a bell is rung in the Capitol Building and surrounding offices and members pour through the corridors and the tunnels which connect their offices to Congress into the chamber.

\section{Floor debate}

The chambers of the House and Senate are where all legislation begins its life and, for the bills which have survived the committee stages, where they complete their Congressional journey. Floor debates are the showpieces of Congress, but much of their business is procedural and mundane. Each morning both the House and Senate start the day with a prayer and, since 1989, the House has followed the prayer with members reciting the Pledge of Allegiance. Each week in 'morning business' in the Senate or 'morning hour' on Mondays and Tuesdays in the House (which, strangely, lasts for an hour and a half), time is also given over for members to give a five-minute speech on any topic they choose.

The debates determine the final fate of legislation. When a bill has been reported by a committee and placed on the calendar of the House or Senate it will be debated and subjected to attempts to amend it before a vote is taken on its final passage. For the vast majority of legislation, all that is needed is the approval of a simple majority of members voting in each chamber to pass into law.

\section{House}

Officially, it is the Speaker who chairs sessions in the House chamber, but apart from the most prestigious or politically 
important business, the duties are given to a more junior colleague to perform. Over the course of a normal day a number of Representatives will preside in place of the Speaker, calling the House to order, recognising members who wish to speak, ruling on points of order and overseeing voting procedures.

The structure of a debate on a bill on the House floor is determined by the rule (discussed in chapter 5). An example of a rule is given in Box 6.1. In this example the terms of debate are established for a bill concerning safety in transportation. It states that 'any time after the adoption of this resolution the Speaker may ... declare the House resolved into the Committee of the Whole House on the state of the Union for consideration of the bill'. This is a procedural device to allow the debate to take place. Any meeting of the full House requires that half the total membership, some 218 members, be present before business can commence. This is known as a quorum. By resolving itself into the Committee of the Whole, the House can continue with its business with a quorum of only 100 members.

The rule then waives the first reading of the bill, another technical procedure which prevents the lengthy process of the whole bill being read aloud before debate can proceed. It decrees that the time set aside for debate will be evenly divided between the 'chairman and ranking minority member of the Committee on Transportation and Infrastructure'. This determines who will be managing the bill on the floor. The bill managers control the time available for debate and allocate it to members who wish to speak. The job is usually given to the chair and ranking member of the committee which reported the bill, who often work with the party leaders and whips to ensure the passage, defeat or alteration of the bill, depending on their preference. 


\section{Box 6.1 An example of a rule}

\section{7th Congress, 1st Session, H.RES.36}

Providing for consideration of the bill (H.R. 554) to establish a program, coordinated by the National Transportation Safety Board, of assistance to families of passengers involved in rail passenger accidents.

Resolved, That at any time after the adoption of this resolution the Speaker may, pursuant to clause 2(b) of rule XVIII, declare the House resolved into the Committee of the Whole House on the state of the Union for consideration of the bill (H.R. 554) to establish a program, coordinated by the National Transportation Safety Board, of assistance to families of passengers involved in rail passenger accidents. The first reading of the bill shall be dispensed with. General debate shall be confined to the bill and shall not exceed one hour equally divided and controlled by the chairman and ranking minority member of the Committee on Transportation and Infrastructure. After general debate the bill shall be considered for amendment under the five-minute rule. Each section of the bill shall be considered as read. During consideration of the bill for amendment, the Chairman of the Committee of the Whole may accord priority in recognition on the basis of whether the Member offering an amendment has caused it to be printed in the portion of the Congressional Record designated for that purpose in clause 8 of rule XVIII. Amendments so printed shall be considered as read. At the conclusion of consideration of the bill for amendment the Committee shall rise and report the bill to the House with such amendments as may have been adopted. The previous question shall be considered as ordered on the bill and amendments thereto to final passage without intervening motion except one motion to recommit with or without instructions. 
The rule also provides for the amendments under 'the fiveminute rule'. The five-minute rule allows members to propose amendments and allocates five minutes for speeches in favour of each amendment and five minutes for speeches against. However, this time is regularly extended at members' requests.

\section{Senate}

Officially, the Vice-President of the United States is the presiding officer of the Senate. However, this role is usually only fulfilled on ceremonial occasions or when the Senate is tied on a vote and the Vice-President appears to cast the deciding ballot. In the absence of the Vice-President, the job of presiding officer falls to the President pro tempore, traditionally the longest serving member of the majority party. In practice, the President pro tempore will in turn delegate the duties of presiding over debates to other, more junior, members of the majority party.

\section{Filibuster}

The Senate as a whole is more accommodating to individual members' requests than the more formally disciplined House. Debates are often much slower and less focused than those in the House. One of the most important differences between debates in the two chambers is the possibility of a filibuster in the Senate. The Senate has no Rules Committee and instead determines the length and structure of its debates by unanimous consent agreements. Such agreements, however, can be disrupted by a single member. One such disruption is the filibuster. On occasions, a Senator opposed to a proposal (but aware that it is likely to be approved) will hold up proceedings by rising to speak on the Senate floor and once recognised 
by the presiding officer continuing to talk and talk and talk and talk. Once a Senator has the floor, he cannot be stopped from speaking unless he himself yields to another Senator. The idea behind the filibuster is to disrupt proceedings to such an extent that supporters of the proposal will attempt to negotiate a compromise or withdraw the measure entirely. As the Senator continues to talk, no other floor business can take place, forcing other scheduled debates down the calendar; a tactic which is particularly effective in the last days of the Congress. While the filibuster is taking place, proponents of the measure have to try to ensure that their fellow supporters remain close to the Senate floor. At any time, opponents may call for a quorum count and if too few Senators are present, the Senate will adjourn. Alternatively, on an issue where the Senate is closely divided, there is a danger of enough supporters of the measure leaving the Capitol that a vote could be called by the filibustering Senator and the measure may be defeated. These are particular dangers towards the end of the week when Senators are looking to return home to their constituencies. Faced with these problems, the proponents of the measure may choose to withdraw it for another time, or to negotiate.

The filibuster was immortalised in Frank Capra's excellent 1939 film Mr Smith Goes to Washington, where an honest but naive young Senator, Jefferson Smith (played by James Stewart) talks until he collapses to prevent the passage of a resolution expelling him from the Senate on false charges. The most famous instance in real life occurred in 1957 when South Carolina Senator Strom Thurmond spoke continuously for twenty-four hours and eighteen minutes to prevent the passage of civil rights legislation. Thurmond still holds the record for the longest filibuster. As long as they stay on their 
feet during a filibuster, Senators can speak on any subject they wish or, if they like, simply read from a text. Louisiana's legendary former Senator and Governor Huey P. Long was no stranger to the filibuster (once lasting fifteen hours), and would frequently spend the time reading from Shakespeare and cookery recipes for what he called 'pot-likkers'.

In order to prevent filibusters succeeding, the Senate rules were changed in 1917 to adopt the process of cloture. Today, if two-thirds of the Senate (currently sixty Senators) approve, a vote can close the debate, stopping the filibuster. Despite this, the filibuster is still an effective tool, largely because of the difficulty of achieving the two-thirds majority. Aside from the filibuster, Senate debates are traditionally more accommodating of individual members, and not so dominated by a few knowledgeable or experienced members as House debates can often be.

\section{Amendments}

In the Senate, any member can offer any amendment to any bill during the floor debate. They will have the opportunity to rise and propose their amendment, a short debate can take place and then the matter will be put to a vote. The process for offering and debating amendments in the House is the same, but members face restrictions as to the type of amendments which can be offered. Restrictions can be placed by the Rules Committee, who (if their decision is accepted by the House as a whole) can decree all or parts of a bill exempt from amendment. A permanent restriction faced by House members is that an amendment will be ruled out of order if, in the opinion of the Speaker, it is not germane, meaning that the amendment must concern the same issue as the bill it 
seeks to change. In the Senate, non-germane amendments are allowed and, as such, Senators can attempt to attach any provision to any bill, regardless of its relevance.

\section{Purpose of amendments}

While all amendments have the same goal - to change the content of the bill being debated - the motivation behind them can differ greatly. Perfecting amendments seek to correct or improve the legislation. These can be offered for a number of reasons: the supporters of the bill may wish to alter parts in order to reach a compromise which will attract more support in the final vote, members may attempt to attach riders to the bill to ensure their state or district benefits from the legislation, or it may be a genuine attempt to remedy a minor fault in the bill. Wrecking amendments are designed not to make the bill better, but to alter it to such an extent that would make its final passage unlikely. Opponents may offer an amendment which would make the legislation more radical, hoping that enough supporters of the bill will join opponents to vote for the provision, but that the amended bill will persuade wavering members to help defeat the final measure. During the passage of the 1964 Civil Rights Act, Congressman Howard Smith of Virginia, a staunch opponent of the legislation, offered an amendment extending the act to cover discrimination of women. Enough supporters of civil rights approved of this extension, that the amendment was adopted. Smith had hoped that the change would make the bill unpalatable to persuade enough members to join with the existing opponents to ensure its final defeat. The plan backfired however, and the Act along with Smith's amendment eventually passed into law. Substitute amendments seek to replace the bill in its entirety. Opponents will offer a complete alternative to 
the legislation, rather than attempting to form coalitions in support of a series of different amendments. Substitute amendments take a commitment of time and resources to write and will often come from the party hierarchy.

\section{Voting}

Once an amendment has been debated, or the amendment process has been completed and the bill is ready for a final decision, the presiding officer will call for a vote. The procedures differ slightly in the House and Senate.

\section{Voting in the House}

The first vote on an amendment or bill will be a voice-vote. The matter for decision will be announced and all those who support the measure will call 'aye' and all those who oppose it will call 'no'. The presiding officer will then announce which side has appeared to have won. Especially on uncontroversial issues, the opinion of the majority of the House will be obvious and the result will stand. On more closely contested decisions, a recorded vote may be requested at the behest of the necessary number of members (twenty-five in the Committee of the Whole). Through a system of lights and bells in the Capitol Building and surrounding offices, members will be alerted that a recorded vote is taking place, allowing them to make their way to the chamber. Once members arrive, they vote electronically. Each member has a credit-card sized voting card which they place in one of nearly forty voting machines located about the House chamber and press the appropriate button to vote 'yea', 'nay' or 'present'. Members are allowed to vote 'present' when they have no opinion on or knowledge of the issue or do not wish to 
express their opinion, but do not want their constituents to think they were simply absent. As members cast their vote it is registered against their name on a large electronic display above the Speaker's chair. Most votes last fifteen minutes to allow members to come from around the Capitol to vote, but this time limit can be extended at the discretion of the presiding officer. Once the time has elapsed the presiding officer announces the final result.

\section{Voting in the Senate}

There are occasions in the Senate when the process of voting itself is dispensed with. If the mood of the Senate on an issue is obvious, the presiding officer will suggest that 'without objection' the motion is accepted or rejected. If no one objects, the decision stands. Voice-votes and roll-call (recorded) votes are also used by the Senate. Unlike the House, there is no provision for electronic voting. When a recorded vote is called for, Senators gather in the chamber and a clerk calls their names one by one to which they respond with their vote. It is the smaller size of the Senate which makes this possible.

\section{Recorded votes}

Recorded votes are often called for practical reasons, because the House or Senate are evenly divided and the result cannot be precisely obtained by a voice-vote. It can, though, also be a political manoeuvre. Once a member has registered their opinion in a recorded vote, that information is in the public domain and can be viewed by voters or used by opponents in an election campaign. It is also accepted that members should attend a vote whenever physically possible. A poor attendance record in recorded votes can be used by opponents as evidence of a Senator or Representative not doing their job. 
Consequently, calling for a recorded vote can be a tactic by supporters of a measure which they feel has public support to try and compel their colleagues to come to the chamber and publicly register their vote.

\section{Do floor debates change anything?}

In principle, debates encapsulate the essence of representative democracy. The Senators and Representatives chosen by the people, gather to consider legislative proposals and to persuade each other of the best course of action. When the arguments have been made and considered, a free vote decides the outcome. However doubts have been raised as to whether debates in Congress make any real difference.

Speaking in the 1930s, Senator Carter Glass said 'In the twenty-eight years that I have been a member of one or the other branches of Congress, I have never known a speech to change a vote'. ${ }^{1}$ The accusation is that on any one issue, members' minds are made up long before legislation gets to a debate. This can be seen as a function of committee power (members deferring to the wishes of the specialist panel), constituency pressures (members determining the direction of their vote by a judgement as to the attitude of the majority of their voters) or following a party line. In such cases, it could be argued that such factors have more of an impact on the result of the vote than any argument put forward in a debate. Critics of the Congressional process could also point to the fact that in most cases only a small percentage of members who cast votes are actually present on the floor to hear the debate and as such could not have been affected by the arguments put forward there.

New York Congresswoman, Bella Abzug disagrees with this assessment. Writing in 1972 she argued 
There is a theory around here ... that to attend a debate on the floor is a waste of time. Since everybody has his mind made up in advance, the theory goes, what's the point of going to a debate? ... Well that's the theory, and I, obviously, don't buy it. I hardly ever leave the Floor when the House is in session, because what I was sent here to do is sit and watch and participate. Besides, I don't think debate is a waste of time. I have seen my own arguments sway votes. ${ }^{2}$

Often speeches in debates are not aimed at persuading other members listening. They can be strategic tools designed to state a member's position for public consumption or to satisfy an interest group. Alternatively, coalition or party leaders can use the debate to indicate their support for a particular measure as a message to their supporters. However, in particularly close votes, the power of argument during a floor debate should not be dismissed. A powerful oration can be essential in persuading wavering opponents or convincing existing supporters to stand by their view.

\section{House-Senate Conference}

Once a bill has been debated, amended and succeeded in a final vote, that is not the end of the legislative process. One of the difficulties presented by a bicameral legislature is that once each chamber has considered the same legislation, with the addition of committee and floor amendments, two very different versions of a bill can emerge. In order for the legislation to be sent to the President for his signature, one single bill, agreed by both the House and Senate is needed. Where the differences are minor or uncontroversial, the process of reconciling the House and Senate is often straightforward. The chamber which first passed the legislation has an opportunity 
to consider the changes made by their opposite number and accept the new version of the bill. If they cannot accept the new version, a House-Senate Conference is called.

The House-Senate Conference committee meets on the Senate side of the Capitol Building. Membership of the conference is determined by the party leaders in the respective chambers, but will usually consists of members (and especially leaders) of the committee or subcommittee which originally considered the issue. These members will have the in-depth knowledge of the issue necessary to negotiate on behalf of the chamber. Shepsle and Weingast have argued that this process in itself increases committee power, by effectively providing its members with a veto over parts of legislation in conference.

The conference itself is a forum for discussion, negotiation and compromise. The two delegations are given the task of producing a single piece of legislation which will be acceptable to both the House and Senate. Sections of the bill can be amended or dropped entirely to facilitate agreement between the conferees. Each side of the conference is expected to defend their chamber's version of the legislation as far as possible, but ultimately they are free to choose on which issues to give way.

In the vast majority of cases, the conferees will reach a compromise agreeable to at least a majority of each delegation. Not all members of the conference will have gained all they wanted, but it is in their interests that a final bill emerge. Only on rare occasions will a conference fail to reach agreement, an eventuality which would doom the legislation at this late stage. Once the conference has finished its deliberations, the final version of the bill is sent back to the floors of the House and Senate for their approval. Attached to the bill will be a 
statement explaining the conference's decisions. If either the House or Senate does not approve of the changes made, they can vote to either recommit the legislation, sending it back to the conference for further consideration, or to reject the bill entirely. However, in practice, the majority conference reports are accepted by the both the House and Senate and the legislation is sent to the White House for the President's signature.

In itself, the decision to call a conference, rather than accept the other chamber's version, can be politically motivated and controversial. In February 2002, campaign finance reform legislation was up for debate on the House floor having successfully passed the Senate some months before. The Republican House leadership opposed the legislation, but were aware that it was likely that enough Republicans would join with the Democrats to pass the bill. One tactic opponents of the legislation used was to offer multiple amendments in an attempt to make the House's version of the bill sufficiently different from the Senate. They hoped that if they succeeded, the Senate would be reluctant to accept the House's alterations and a House-Senate conference would be called. With the majority party leadership able to influence which House members would be sent to the conference, there was a serious threat that the bill would not survive a conference or that it would be significantly altered. The attempt was unsuccessful, however, as with only minor differences between the two versions, the Senate accepted the House bill with no need for a conference.

\section{Summary}

If a bill is to become a law, it must gain the approval of both the House and Senate in a floor debate. For most legislation, a simple majority is required. The procedures for debating 
and voting are similar in the House and Senate, although the rules of the Senate afford individual members more scope to disrupt proceedings. The floor debate also gives members an opportunity to offer amendments to legislation. The motivation behind such amendments can vary. If different versions of the same bill emerge from the House and Senate, it is often necessary to call a House-Senate Conference to iron out the differences before the bill can be sent to the White House for the President's signature.

\section{Notes}

1 P. F. Boller Jr., Congressional Anecdotes (Oxford: Oxford University Press, 1991), p. 181.

2 Ibid. 